\title{
Uma avaliação empírica da competição eleitoral para a Câmara Federal no Brasil
}

\author{
Glauco Peres da Silva \\ Núcleo de Estudos Comparados e Internacionais (NECl) \\ Universidade de São Paulo \\ Centro de Estudos da Metrópole (CEM) - CEBRAP
}

\begin{abstract}
Resumo: O objetivo deste artigo é avaliar empiricamente a competição eleitoral para o cargo de deputado federal no Brasil e a sua dimensão regional, que se apoia nos conceitos de distritos eleitorais informais (AmES, 2001; 2003) ou grotões políticos (HUNTER E POWER, 2007; ZUCCo, 2008). Este artigo considera as eleições entre 1994 e 2010 e utiliza um indicador de desequilíbrio (TAAGEPERA, 1979) em análise temporal como critério básico da avaliação do controle regional do voto, já que o Número Efetivo de Partidos (NEP) não capta a descentralização da disputa eleitoral. Os resultados indicam que a ausência de competição não é regra da disputa política no país, que a tese dos distritos eleitorais carece de evidência empírica e que os políticos que evitam a competição nem sempre se elegem e não são os mesmos em uma mesma localidade ao longo do tempo.
\end{abstract}

Palavras-chave: competição eleitoral; distritos informais; deputado federal; grotões; Índice T

Abstract: The aim of this paper is to empirically evaluate the electoral competition in the Brazilian election for Congress. The evaluation focused on the regional dimension of electoral competition, what is sustained by concepts such as informal electoral districts (AMES, 2001; 2003) or political hamlets (HUNTER AND POWER, 2007; ZUCCO, 2008). This paper considers electoral results from 1994 to 2010 and uses the imbalance index (TAAGEPERA, 1979) in a timing frame perspective as basic criteria because the Effective Number of Parties does not capture the decentralization of electoral competition. Results suggests that the personal and regional political control is not the rule of political competition in Brazil; the informal district theory lacks of empirical support and, the politicians that are successful in avoiding competition do not always get elected and vary in their power over electorate through time.

Keywords: electoral competition; congressman; hamlets; Index T 
OPINIÃO PÚBLICA, Campinas, vol. 19, n², novembro, 2013, p. 403-429

\section{Introdução*1}

A avaliação da competição eleitoral é um antigo fenômeno de interesse da Ciência Política. Desde Duverger (1951), as regras eleitorais, balizadoras daquela competição, tornaram-se pontos relevantes da análise do sistema político de qualquer país. A chamada "Lei de Duverger" abriu caminho para inúmeros trabalhos que avaliam empiricamente diferentes sistemas eleitorais em vários países (p.ex., RAE, 1967 e LIJPHART, 1990). Como resultado destes trabalhos, observa-se que sistemas proporcionais apresentam maior número de partidos do que sistemas majoritários, o mesmo acontecendo na comparação entre distritos multimembros com aquele onde se elege um único representante (SCHOFIELD et al, 1998).

O debate sobre o caso brasileiro, que nas eleições para as Câmaras de Deputado Federal e Estaduais adota o sistema proporcional de lista aberta em distritos multimembros, caminhou para a interpretação de que a competição dar-se-ia entre os candidatos de uma mesma lista, o que enfraqueceria os partidos políticos e, ao mesmo tempo, incentivaria os candidatos a concentrarem seus esforços espacialmente. Tentariam, desta maneira, criar redutos nos quais trocariam votos por apoio político. Assim, haveria esta dupla dimensão ao se tratar de competição eleitoral no Brasil: por um lado, os candidatos disputariam entre si uma posição de destaque na lista de seu partido, acirrando a competição, mas, por outro, tenderiam a criar áreas nas quais controlariam o eleitorado, evitando a disputa (MAYHEW, 1974; MAINWARING, 1991; LAMOUNIER, 1989; AMES, 1995a; 1995b; 2001, entre outros). Esta interpretação, que faz com que Ames afirme existir distritos eleitorais informais, está em linha tanto com o conceito de conexão eleitoral, quanto com a visão arraigada no senso comum sobre a existência de grotões políticos: "pequenos municípios pobres do país" (JACOB et al, 2009) também de baixa escolaridade (CAMPELlo e ZUCCO, 2008) que estariam sujeitos ao controle político individual ${ }^{2}$. Neste cenário, o incentivo seria por evitar a competição individual regional a todo custo.

Parte da literatura, como Nicolau (2006) e Braga (2006), já buscou identificar a disputa interna à lista. Argumentam que a disputa de fato existe e é elevada, confirmando os incentivos proporcionados pelas regras eleitorais. Porém, a literatura ainda não tratou da dimensão regional da competição. Esta pode ser subdividida em dois aspectos: o nível de competição regional propriamente dito e a insistência de um político como o deputado federal associado a regiões particulares que consegue evitar a disputa. Contrariamente à transposição do modelo de conexão eleitoral americana, trabalha-se com a hipótese alternativa de que os incentivos eleitorais não são fortes o suficiente para que os políticos consigam

"Além de Pesquisador Associado do NEC.FFLCH/USP e do CEM-CEBRAP, o autor é professor do Mestrado Profissionalizante em Administração da Fundação Escola de Comércio "Álvares Penteado" (FECAP).

${ }^{1} \mathrm{O}$ autor agradece ao grupo de Estudos Eleitorais do Cebrap, notadamente a Fernando Limongi e a Andreza Davidian, e aos participantes no seminário organizado pelo Cepesp/FGV, na figura do prof. George Avelino Filho. Os comentários foram relevantes para a execução deste trabalho, mas as observações de praxe sobre a responsabilidade do texto permanecem. Este artigo foi financiado pelo Centro de Estudos da Metrópole (CEBRAP, USP), processo n 2013/07616-7, Fundação de Amparo à Pesquisa do Estado de São Paulo (FAPESP). As opiniões, hipóteses e conclusões ou recomendações expressas são de responsabilidade do autor e não necessariamente refletem a visão da FAPESP.

2 Para Soares e Terron (2008), grotão refere-se a áreas de apoio a partidos conservadores, inclusive aqueles que suportavam a ditadura militar. Esta imagem está associada ao favorecimento do status quo, que permaneceria no poder através do controle de regiões concentradas nas áreas mais pobres do país (MONTERO, 2010). Em outras análises (HUNTEr e POWER, 2007 e ZUCCO, 2008), esta abordagem se repete ao buscar compreender o sucesso eleitoral de Lula. Porém, de acordo com Santos (2006) e Velho (2006), esta interpretação, ainda concordante com a imagem do coronelismo de Vitor Nunes Leal, não mais corresponderia à realidade, mas ainda permaneceria não só no imaginário popular, como também, segundo Santos, ainda influenciaria as análises acadêmicas. 
SILVA, G. P. Uma avaliação empírica da competição eleitoral para a Câmara Federal...

evitar a disputa com candidatos de outros partidos, nem que seja de seu interesse permanecer em sua carreira política apenas como deputado federal, condições para a existência da conexão eleitoral. A dificuldade em evitar a competição local baseia-se na inexistência de restrições institucionais a que um deputado envie pork para qualquer região do estado ou que faça campanha em áreas que seriam de outros; ainda, sabe-se que a participação do prefeito nas disputas eleitorais para a Câmara Federal tem influência positiva sobre o total de votos que os candidatos a deputado do mesmo partido recebem (AVELINO et al, 2012); e também é sabido que os deputados federais não adotam padrão estático de carreira, inclusive por manifestarem preferência por cargos executivos (SAMUELS, 2003; MARENCO DOS SANTOS, 1997). Ademais, deve-se ressaltar que compreende-se que a competição seja uma característica do território ${ }^{3}$, e não dos políticos. Estes podem intencionar concentrar seus votos em determinada região, mas é da combinação das ações do conjunto de candidatos que se avaliará se a eleição em determinada localidade é ou não competitiva.

É neste contexto que este artigo busca avançar o debate sobre a competição eleitoral para as eleições legislativas brasileiras. Para avaliá-la, são investigadas as disputas para o cargo de deputado federal, resgatando o indicador de desequilíbrio T de Taagepera (1979), com enfoque na preponderância individual nos resultados das eleições por município ao longo do tempo. O índice de desequilíbrio permite avaliar a participação não só do candidato mais votado em cada localidade, mas também dos demais, consequentemente, indicando o nível de competição eleitoral. Além disto, é fundamental que se verifique a permanência do deputado neste cargo, uma vez que a sua dominância política perene é a base teórica da tese da ausência de competição eleitoral. Os resultados encontrados aqui sugerem que as eleições para deputado federal no Brasil são competitivas e que esta competição acontece por todo o país. É possível demonstrar que a competição eleitoral varia regionalmente no Brasil, respondendo ao nível de urbanização das cidades, mas também que o nível de disputa vem crescendo ao longo do tempo em todo o país. As capitais são mais competitivas do que as demais cidades, mas não há indícios de que regiões mais pobres ou menos populosas sejam menos competitivas do que as demais. Além disso, o aumento no número de prefeitos do estado acaba por tornar as eleições em todos os seus municípios menos competitivas, o mesmo acontecendo com relação à representação pelo número de cadeiras em disputa: quanto mais sobrerrepresentado um estado no Congresso Nacional, menor o nível de competitividade das eleições ali.

Para cumprir seu intuito, o artigo primeiro discute as análises existentes sobre o sistema eleitoral brasileiro, focando nas mensurações utilizadas para caracterizá-lo segundo a competição eleitoral. Em seguida, apresenta uma visão sobre a competição eleitoral para, depois, demonstrar empiricamente esta tese com a análise da competição nas eleições para deputado federal entre 1994 e 2010. Em seguida, são feitas as considerações finais.

${ }^{3}$ Importante dizer que, ao contrário do que se propõe aqui, a discussão apresentada em Avelino et al se refere às características dos candidatos em disputa. A análise desses autores é, portanto, complementar à discutida aqui. 


\section{Consequências do Sistema Eleitoral Brasileiro}

A relação entre os sistemas eleitorais e o sistema político como um todo vem sendo objeto de análise sistemática por muitos pesquisadores. Desde autores fundamentais, como Rae (1967) e Lijphart (1990), as principais variáveis do sistema eleitoral, como magnitude do distrito e fórmula eleitoral, estão intimamente vinculadas aos resultados das eleições, analisados pelo grau de proporcionalidade da representação e pelo número de partidos. Consequentemente, trabalhos contemporâneos buscam compreender as implicações decorrentes das regras eleitorais sobre o funcionamento dos sistemas políticos nacionais ${ }^{4}$. Um texto clássico neste sentido é o de Carey e Shugart (1995), que avalia a influência do sistema eleitoral sobre o voto pessoal ${ }^{5}$. O caso brasileiro também tem sido pensado a partir desta perspectiva.

De acordo com a interpretação tradicional sobre o funcionamento do sistema político brasileiro, que culmina com as dificuldades institucionais do Poder Executivo em governar o país, a origem dos males políticos está nas regras eleitorais ${ }^{6}$, redundando na conexão eleitoral. Definição criada para explicar originalmente o sistema político americano (MAYHEW, 1974; CAIN; FEREJOHN e FIORINA, 1987), esta justifica a dinâmica legislativa dispersiva e o consequente enfraquecimento dos partidos no Brasil (LAMOUNIER, 1989; MAINWARING, 1991). Seguindo esta interpretação, as regras eleitorais brasileiras imporiam comportamento individualizado entre os candidatos a deputado ao promover a disputa inclusive entre companheiros de legenda, pois apresentariam como objetivo individual colocar-se o melhor possível na lista aberta fornecida ao eleitorado. Em decorrência, o elevado número de candidatos e partidos na disputa e a necessidade de cada candidato buscar recursos para sua campanha acabariam por incentivar o voto pessoal (SAmUELS, 1999; NiCOLAU, 2006). Resultante desta identificação pessoal entre candidatos e eleitores, os deputados, uma vez no Congresso, atuariam com vistas a retribuir os votos recebidos pelo atendimento de demandas locais via pork em detrimento do debate sobre questões nacionais. A localidade para a qual o deputado volta as suas ações no Congresso, também chamada de distrito eleitoral informal, constituiria sua zona de dominância política e se estabeleceria uma relação pessoal de troca entre pork e votos (AmES, 1995a; 1995b; 2001; PEREIRA e RENNó, 2001, entre outros).

Nesta abordagem, Ames propõe uma mensuração do nível de dominância obtido por um deputado em dada eleição. O autor define quatro tipos de distribuição de votos: concentrada-dominante; concentrada-compartilhada; fragmentada-dominante; e fragmentada-compartilhada. Dentro destes grupos, ele enfatiza que as estratégias eleitorais direcionariam os candidatos a buscarem votos em suas áreas de dominância e, nos casos de votação dispersa, angariar votos em segmentos discretos de eleitores, uma vez que os distritos eleitorais são muito grandes. Como os candidatos ao Legislativo competiriam por espaço físico, eles buscariam estabelecer-se em municípios onde os eleitores e os líderes políticos locais os apoiam. É nas cidades que os políticos estabeleceriam seu apoio político, com foco na formação de redutos eleitorais. A preocupação de cada deputado é, assim, garantir que nenhum

${ }^{4}$ Como exemplo, Queralt (2009) trata do efeito das eleições repetidas sobre o comportamento dos eleitores; Amorim Neto e Cox (1997) avaliam a relevância da permissividade do sistema eleitoral sobre o número de partidos.

5 Para uma discussão mais atualizada, vide Crisp, Jénsen e Shomer (2007).

6 Para uma excelente apresentação do funcionamento das regras eleitorais no Brasil e sua importância em diferentes aspectos do sistema político, vide Nicolau (2006). 
SILVA, G. P. Uma avaliação empirica da competição eleitoral para a Câmara Federal...

outro político se arrisque a buscar votos em suas regiões. Cada deputado buscaria proteger estas áreas, formando redutos de controle político.

Por esta perspectiva, portanto, não há espaço para a competição política. Competição e concentração de votos são faces de uma mesma moeda. Os deputados, ao conseguirem concentrar seus votos, evitam a existência de qualquer concorrência, notadamente em seus redutos eleitorais. Levada ao extremo, a tendência do sistema é a formação de um conjunto de redutos eleitorais onde os deputados federais estabeleceriam uma relação clientelista baseada na pork barrel politics. Ainda que uma região fosse declarada compartilhada, os incentivos para o comportamento paroquial permaneceriam (MELO, 2005), sem que se observasse qualquer competição eleitoral. Nesta perspectiva, falar sobre competição eleitoral carece de sentido teórico, o que, de outra forma, reforça a visão comum sobre a formação e manutenção dos grotões políticos no país.

Entretanto, sob outra perspectiva, há autores que criticam essa visão e observam excessivo nível de competição eleitoral. Por exemplo, Kinzo et al (2004) apresentam que, entre 1986 e 2002, a representação partidária na Câmara dos Deputados brasileira foi altamente fragmentada. Utilizando o Número Efetivo de Partidos (NEP), os autores encontraram aproximadamente oito partidos efetivos entre as eleições de 1990 e de 2002, demonstrando elevada volatilidade eleitoral para o período. Ainda, Limongi (2006) analisa as votações nas coligações por município para avaliar a competição eleitoral no Brasil. Sua análise descritiva mostra que não procede a ideia da ausência de competitividade nas eleições brasileiras, nem que municípios pequenos sejam não competitivos, já que candidatos que concorrem por listas partidárias distintas recebem votos na grande maioria das cidades. Mas, como o próprio autor afirma, é preciso encontrar formas mais sofisticadas de avaliar competição.

O diagnóstico sobre competição eleitoral derivada da conexão eleitoral não incorpora alguns incentivos presentes no sistema político brasileiro que podem alterar o debate. Em primeiro lugar, não há nenhuma razão institucional para se afirmar que os deputados atuem com vistas a atender apenas a uma determinada área do distrito eleitoral (FIGUEIREDO e LIMONGI, 2008). Qualquer deputado pode, por exemplo, propor emendas eleitorais para qualquer cidade, a despeito da quantidade de votos que tenha recebido ali. Seria possível imaginar, por exemplo, que um deputado utilizasse este instrumento para expandir a sua zona de influência, invadindo áreas que seriam redutos de outros deputados. Nem há mecanismos para que um deputado evite que outros façam campanhas em sua região. Um político não possui meios para impedir que outros busquem votos em sua área de interesse, principalmente candidatos de outros partidos. Além disto, o resultado da eleição para prefeito, que se dá no meio do mandato dos deputados federais, tem importância para o desempenho dos candidatos a deputado. Pode-se supor que um deputado com uma área geográfica de eleitores bastante definida veria aumentar a concorrência nas eleições seguintes se políticos de partidos de oposição ganhassem as prefeituras das cidades desta área (CARNEIRO e ALMEIDA, 2008; AVELINO et al, 2012). Por fim, a argumentação proposta por Ames (1995a) assume implicitamente que um deputado que forme um reduto buscará disputar eleições futuras neste mesmo cargo. Afinal, esta seria a maneira de sustentar o seu reduto ao longo do tempo. Porém, outros autores (p.e., Samuels, 2003, p. 18), evidenciam que os deputados não só não 
permanecem em uma estratégia de carreira estática, como manifestam preferência por cargos executivos. Tal situação provocaria o surgimento de oportunidades para que outros políticos se elejam deputado com os votos daquela região. Se confirmada, esta alternância provocaria algum grau de competição entre políticos pelos votos de uma determinada localidade. Assim, este arranjo institucional que deriva das regras eleitorais brasileiras surge como fator relevante para a competição eleitoral individual para os cargos legislativos no Brasil.

Já no que tange a aspectos metodológicos, apesar de apresentar avanços consideráveis sobre o funcionamento do sistema político nacional, a utilização do NEP camufla a própria fragmentação do sistema. Por exemplo, o apontamento da existência de oito partidos em média para o período de 1986 a 2002 não informa se são oito grandes partidos ou se alguns destes partidos efetivos correspondem à junção de partidos menores, um caso de elevada fragmentação. Seria possível, por exemplo, que houvesse quatro partidos grandes e outros tanto menores que, ao serem agregados pela regra de cálculo do indicador, comporiam os oito encontrados. Neste sentido, a sua utilização não dá conta de explicar uma dificuldade inerente ao sistema político nacional que é a sua alta fragmentação. Este cenário torna. se ainda mais dramático ao se investigar a competição com referência aos próprios candidatos. Ao avaliar se há formação de distritos eleitorais informais, é fundamental analisar a competição eleitoral individual, pois serão os deputados que disputarão influência sobre o território e buscarão garantir que outros políticos não interfiram em suas áreas ao longo do tempo. Assim, é necessário não só buscar uma nova forma de mensurar a competição eleitoral individual, como também é preciso introduzir sua análise temporal, notadamente no nível subnacional, pois, se há estabilidade na relação política com o eleitorado, deve-se avaliar como se dão as disputas políticas ao longo do tempo.

\section{Definição e Mensuração da Competição Eleitoral}

A interpretação tradicional sobre o sistema político brasileiro apresenta duas dimensões de análise com relação à competição eleitoral: a disputa pelo posicionamento dentro da lista partidária e a distribuição espacial doso votos de cada deputado. Na primeira dimensão, os candidatos a deputado federal concorreriam entre si, principalmente com companheiros de legenda, para obter número mais elevado de votos e, consequentemente, melhor posição na lista partidária ou da coligação. Esta dimensão, que pode ser chamada de interna, se dá em razão da adoção da lista aberta para eleições proporcionais. Os políticos se veem obrigados a trabalhar ao longo da campanha em prol de uma colocação de destaque dentro da lista de seu partido de forma a elegerem-se. Quanto à segunda dimensão, os deputados eleitos buscariam delimitar áreas específicas dentro do distrito eleitoral de forma a reduzir os seus custos de campanha, como também a possibilitar o direcionamento de recursos públicos federais através de práticas clientelistas. Esta dimensão da competição eleitoral, que pode ser chamada de regional, conduziria os deputados a evitar a disputa em áreas que seriam de seu interesse particular. Cada político possuiria, assim, uma região específica no distrito para a qual direcionaria seus esforços ao longo do mandato, o que reduziria os custos de campanhas futuras. Há, assim, um duplo incentivo que é aparentemente contraditório: dentro da lista, os candidatos disputam votos entre si; mas, desde que os candidatos atinjam regiões distintas do estado, seus esforços se somam para eleger maior número de representantes. 


\section{SILVA, G. P. Uma avaliação empírica da competição eleitoral para a Câmara Federal...}

Dentro da perspectiva espacial da disputa eleitoral, há dois desdobramentos relevantes que a caracterizam. O primeiro está relacionado à concentração regional dos votos. Desde Ames (1995a, 1995b), associa-se a disputa eleitoral para cargos legislativos à garantia da formação de um distrito informal. Em cada área, o deputado exerceria a sua dominância e, nos casos em que não fosse possível a vinculação espacial, o político elegeria um segmento definido do eleitorado para focar seus esforços enquanto representante na Câmara. Cabe destacar que trabalhos mais recentes, como Avelino et al (2011), avançam nesta discussão ao aplicar indicadores mais precisos sobre a concentração regional do voto e acabam contemporizando os resultados previstos pela literatura ao mostrar que a concentração não parece ser a estratégia adotada pelos deputados. De qualquer maneira, a formação destas áreas assemelhar-se-ia à formação dos grotões, áreas mais afastadas dos centros urbanos, em geral menos desenvolvidas, e onde os políticos teriam maiores condições de perpetuarem-se no poder (MONTERO, 2010; CAMPELlo e ZuCCO, 2008). Estas áreas estariam mais sujeitas à dominância política, onde o controle político conservador seria mais presente, o que está de acordo com a formação dos distritos informais.

O segundo desdobramento do aspecto regional da competição eleitoral vincula-se ao controle sobre os votos do eleitorado. Ainda de acordo com a interpretação tradicional, o deputado, ao criar um reduto de interesse, procuraria atender este eleitor com o envio de recursos públicos em uma clara prática clientelista. Estes redutos seriam evitados pelos demais políticos, resultando em um ambiente sem competição. Isto implica uma análise temporal: o deputado precisa se reeleger caso tenha a intenção de manter o mesmo grau de influência política na área. Para o caso de concorrer a outro cargo, como o de prefeito, abre espaço para outro indivíduo assumir seu posto e contestar sua influência na região. Assim, a análise temporal torna-se fundamental para a análise da competição regional.

Nesse sentido, Pereira e Rennó (2007) afirmam que a taxa de renovação da Câmara é baixa, já que $68 \%$ dos deputados, em média, procuram manter-se no cargo e que $67 \%$ destes obtêm a reeleição. Isto implica dizer que, em média, 54\% dos deputados de uma legislatura não estiveram na legislatura anterior. Ademais, considerando-se que a escolha de recandidatar-se é endógena, uma vez que o deputado possui alguma informação sobre suas chances de reeleger-se, e ainda que, em média, 56\% dos deputados eleitos estejam em seu primeiro mandato, gerando o número médio de mandatos para toda a Câmara igual a 1,7 (MARENCO DOS SANTOS, 1997), parece pouco convincente afirmar que os deputados federais adotam uma estratégia de carreira estática. De qualquer maneira, a opção pela carreira estática é um fato ainda contestável. O deputado tem condições de evitar a competição desde que, pelo menos, permaneça na disputa por este cargo e, desta forma, tenha condições práticas de continuar como líder político daquela área.

Assim, a fim de observar a competição eleitoral regional de votos no Brasil, é preciso lançar mão de indicadores apropriados para a mensuração da competição. A competição eleitoral está vinculada ao grau de disputa pelos votos dos eleitores entre os diferentes concorrentes, sejam candidatos ou partidos. Uma eleição será mais competitiva se houver número maior de candidatos do que o número de cadeiras em disputa (CARAmanı, 2003, p. 416). Porém, uma eleição não é competitiva 
se, mesmo havendo mais candidatos do que cadeiras em disputa, um candidato predominar sobre os demais e conseguir a grande maioria dos votos. Assim, quanto menor a margem de votos obtida pelos candidatos mais votados em relação aos demais, mais competitiva a eleição naquela localidade (CARAMANI, 2003, p.417)7. Esta definição é proposta como base para a mensuração de competição eleitoral neste artigo.

Particularmente à mensuração da competição eleitoral, a literatura internacional adota diferentes parâmetros de análise. Em termos gerais, utiliza-se o número efetivo de partidos, a margem percentual de vitória do candidato eleito ou o total de votos ou cadeiras obtidos pela oposição. Há também trabalhos que consideram a diferença de votos entre o último eleito e o primeiro não-eleito. Holbrook e Van Dunk (1993) propõem um indicador que considera estes diferentes aspectos simultaneamente: percentual de votos recebidos pelo candidato vencedor, a sua margem de vitória, quão "segura" é a cadeira e se a disputa foi ou não contestada. Estes representam, em linhas gerais, os diferentes meios utilizados para mensurar a competição.

Estes índices operam adequadamente quando o sistema é majoritário ou está organizado em distritos que elegem apenas um representante. No caso de sistemas proporcionais organizados em distritos multimembros com listas abertas, estas medidas são insuficientes. Um candidato pode se eleger mesmo que não obtenha mais votos do que candidatos de outras listas, simplesmente em razão de sua lista ter recebido mais votos do que as demais ${ }^{8}$. Além disto, um político pode se candidatar por um partido em determinada eleição e por outro na seguinte, ou ainda não concorrer ao mesmo cargo. Estas situações dificultam, por exemplo, trabalhar com a margem com a qual o político se elegeu ou com o grau de contestação da cadeira entre eleições. Deve-se, portanto, lançar mão de outra forma de avaliar a competição local em sistemas como estes.

É importante observar que a competição eleitoral deve ser vista como um atributo da localidade de análise. Os candidatos podem buscar votos em várias localidades simultaneamente e dependem delas para seu sucesso eleitoral. Mas o nível de competitividade de cada cidade é o resultado das ações dos diversos candidatos em busca de voto. A decisão do candidato está em escolher as regiões nas quais fará campanha; mas o nível de competição será a resultante das ações de todos eles, de acordo com sua capacidade de convencer o eleitorado. Se muitos candidatos buscarem votos em uma mesma cidade, a disputa ali tende a ser mais acirrada do que se o número de candidatos for menor. Neste sentido, a mensuração do grau de competitividade de uma eleição qualquer deve ser direcionada às regiões de interesse.

A ampla gama de índices existentes na literatura das Ciências Sociais pode ser agrupada em quatro dimensões: concentração, desigualdade, privação ou perda e desequilíbrio (TAAGEPERA, 1979). De acordo com Taagepera, índices de concentração focam na comparação entre o maior componente e o

7 Deve-se observar que o intuito está em mensurar a competição em cada localidade particular e não do sistema como um todo. Este ponto merece destaque, pois busca-se abordar a relevância da fragmentação da participação nas eleições em torno da figura dos candidatos individualmente.

8 É bastante conhecida a estratégia da inserção de "puxadores de voto" nas listas de candidatos para deputado federal no Brasil. Estes seriam figuras de grande apelo público que, embora não sejam políticos profissionais, seriam incluídos na lista de forma a aumentar o número de cadeiras ganhas por aquele partido ou coligação. O caso do palhaço Tiririca, eleito com mais de um milhão de votos em 2010, é o mais recente e de grande repercussão na mídia do país. 
SILVA, G. P. Uma avaliação empírica da competição eleitoral para a Câmara Federal...

tamanho total de uma composição - o índice Herfindahl-Hirschman estaria nesta categoria. Já índices de desigualdade comparariam o maior e o menor componentes, sendo o índice de Gini um exemplo. O índice de privação compararia o menor componente com o valor zero. Por fim, o autor, ao argumentar que não há nenhum índice de desequilíbrio aplicado às Ciências Sociais, propõe um indicador que avalia a relação entre cada par de observações simultaneamente. Esta seria uma característica desejada, pois focaria basicamente nas diferenças destes tamanhos relativos. Assim, uma aplicação para o problema deste artigo é representada pela expressão:

$$
T_{m}=\frac{\sum_{i=1}^{\infty}\left[\frac{\left(P_{i, m}-P_{i+1, m}\right)}{i}\right]-H_{m}^{2}}{\sqrt{H_{m}}-H_{m}^{2}}
$$

onde T é índice de desequilíbrio para a cidade "m", P é o percentual de votos do i-ésimo candidato na cidade "m" e H é o índice Herfindahl-Hirschman na cidade "m". Note que os candidatos devem ser ordenados e o índice está restrito ao intervalo entre zero e um, mostrando o nível de disputa eleitoral na cidade. O termo H é incluído, segundo Taagepera (1979, p. 284), como uma forma de eliminar a "correlação residual" com o próprio termo $\mathrm{H}$, já que o somatório do numerador varia entre os limites de $\sqrt{H}$ a $H^{2}$. Considerando-se, então, os votos recebidos pelos diversos candidatos, quanto maior o valor do índice, mais desequilibrada a distribuição de votos em determinada cidade, ou seja, menos acirrada a disputa, pois alguém desequilibrou a eleição em seu favor. Portanto, o nível de competição de um local qualquer está inversamente relacionado ao resultado do índice: quanto mais próximo a zero, maior a competição.

Como ilustração da importância deste indicador, replica-se o mesmo exemplo tratado por Taagepera (1979). Suponha duas cidades nas quais 40 candidatos receberam votos em determinada eleição. Na primeira cidade, dois candidatos receberam 30\%, um terceiro recebeu 3\% e os demais receberam, cada um, $1 \%$ dos votos da cidade. Na segunda, um candidato recebeu $40 \%$ dos votos, outros dois receberam $10 \%$ cada, um quarto recebeu $4 \%$ e os demais receberam também $1 \%$. Taagepera (1979, p. 283) mostra que os índices tradicionais de desigualdade e de concentração não captam as diferenças apresentadas nestas duas cidades. Seus resultados são iguais nos dois casos: como exemplo, o índice H calculado em cada cidade tem valor igual a 0,185. Porém, a utilização do índice T mostra que, na primeira cidade, o desequilíbrio é igual a 0,26, enquanto na segunda é igual a 0,73. 0 desequilíbrio na segunda cidade é maior, resultante da consideração dos votos de todos os candidatos. Não haveria condição de captar esta diferença se fossem utilizados índices tradicionais. A fim de melhorar a interpretação dos resultados, um conjunto de simulações foi feito para indicar a sensibilidade do índice em diferentes contextos. Os resultados são apresentados no Apêndice 1.

É importante ressaltar que, se calculado o número de candidatos efetivos com a fórmula do NEP, o resultado seria igual a 5,4 candidatos por cidade. Entretanto, a primeira cidade possui dois 
candidatos com elevado percentual de votos e o restante está dividido entre outros 38 candidatos. 0 índice acaba por camuflar a elevada dispersão dos votos em torno de muitos candidatos que foram pouco votados, pois os agrega, sugerindo haver um número expressivo de candidatos que disputariam os votos de determinada localidade. 0 fato de o índice de desequilíbrio ponderar as diferenças sucessivas temporalmente capta alterações importantes como a disputa em torno do segundo lugar e a distância deste para o primeiro lugar, o que é fundamental para a avaliação da competição eleitoral. Deve-se notar que este índice distingue as situações em que um candidato possui $50 \%$ dos votos e o segundo colocado tenha recebido, por exemplo, $10 \%$ dos votos, de outra situação em que o primeiro obtenha os mesmos $50 \%$, mas o segundo possua $49 \%$ dos votos. A aplicação do índice proposto permite este avanço sobre a mensuração tradicional, captando uma característica da competição eleitoral brasileira. No Apêndice 2, constam gráficos correlacionando o índice T e o NEP calculados para as eleições brasileiras.

Deve-se enfatizar ainda que o indicador proposto tem a capacidade de avaliar adequadamente casos extremos. Se aplicado a um caso em que determinado candidato obtém $100 \%$ dos votos, o valor observado pelo índice T será igual a um. Por outro lado, se os candidatos dividirem igualmente os votos, o valor observado será igual a zero. Esta característica é desejável, uma vez que aponta sua capacidade em alcançar casos extremos, mesmo que não se espere que aconteçam. Argumenta-se, portanto, que este indicador é relevante e adequado para avaliar os níveis de competição eleitoral em qualquer localidade. Com base neste instrumento, lança-se à avaliação dos dados para o país nas eleições de 1994 a 2010.

\section{Análise Empírica}

A partir da discussão teórica, as duas dimensões da competição regional são analisadas a fim de explicar um fenômeno tão complexo como a competição eleitoral para o Legislativo nacional no sistema político brasileiro. A primeira se relaciona à competição eleitoral propriamente dita. A segunda diz respeito à permanência de um indivíduo como líder político local. Para iniciar a análise empírica, calcula-se o indicador $\mathrm{T}$ para todas as cidades do país. Cabe destacar que este indicador pode ser calculado tomando o conjunto total de votos em cada município ou outro corte. Neste artigo, privilegia-se a análise computando apenas os votos nominais, excluindo-se votos nulos, brancos e de legenda. Esta opção considera a importância do caráter pessoal da dinâmica política local e, assim, identifica a competição entre os candidatos, em linha com a concepção teórica apresentada. A Tabela 1 apresenta os dados obtidos: 
SILVA, G. P. Uma avaliação empírica da competição eleitoral para a Câmara Federal...

Tabela 1

Dados Descritivos para o Índice T por eleição

\begin{tabular}{|l|l|l|l|l|l|}
\hline & 1994 & 1998 & 2002 & 2006 & 2010 \\
\hline Média & 0,464 & 0,463 & 0,460 & 0,433 & 0,412 \\
\hline Desvio Padrão & 0,213 & 0,214 & 0,207 & 0,199 & 0,194 \\
\hline Mínimo & 0,037 & 0,052 & 0,054 & 0,039 & 0,039 \\
\hline Máximo & 0,961 & 0,961 & 0,947 & 0,962 & 0,954 \\
\hline Mediana & 0,445 & 0,445 & 0,443 & 0,409 & 0,386 \\
\hline $1^{\circ}$ Quartil & 0,285 & 0,282 & 0,285 & 0,271 & 0,253 \\
\hline $3^{\circ}$ Quartil & 0,632 & 0,638 & 0,627 & 0,581 & 0,549 \\
\hline
\end{tabular}

Os resultados indicam relativa estabilidade nos valores médios para as primeiras três eleições consideradas, em torno de 0,46, valor próximo ao centro do intervalo. Já nos dois pleitos seguintes, as médias caem, atingindo o menor valor da série, em 2010, igual a 0,41. Esta queda é acompanhada da redução do desvio padrão. Este segue o mesmo comportamento observado pela média: nas primeiras eleições, o desvio estava em torno de 0,21 e se reduz para a casa de 0,19 ao final do período. Por outro lado, os valores máximo e mínimo apresentam baixa variação ao longo do tempo. Estes dados mostram que a distribuição do desequilíbrio das eleições locais é dispersa, inclusive com a amplitude observada muito próxima à do próprio índice. Bastante importante é observar que os valores calculados para a mediana também caem ao longo do tempo. Em 1994, como em 1998, o valor é igual a 0,445, em 2010, atinge o menor valor para a série: 0,386. Estes dados, em conjunto, sugerem que os valores de desequilíbrio são relativamente baixos para a maioria das cidades brasileiras e que este desequilíbrio apresenta tendência de queda ao longo das eleições. Ou seja, o nível de competição eleitoral é relativamente alto e vem aumentando para todo o país.

Outra dimensão de interesse é a avaliação regional da competição. Seguindo os autores que discutem a importância dos grotões no contexto político nacional, é esperado que sejam encontradas diferenças importantes entre os resultados regionais. A alta diversidade de características socioeconômicas dos municípios brasileiros permitirá verificar se as regiões mais atrasadas do país são aquelas onde também a competição eleitoral é menor. O Gráfico 1 apresenta as médias para as cinco regiões brasileiras ao longo das eleições: 


\section{Gráfico 1}

Evolução das médias do índice T por região para as cinco eleições

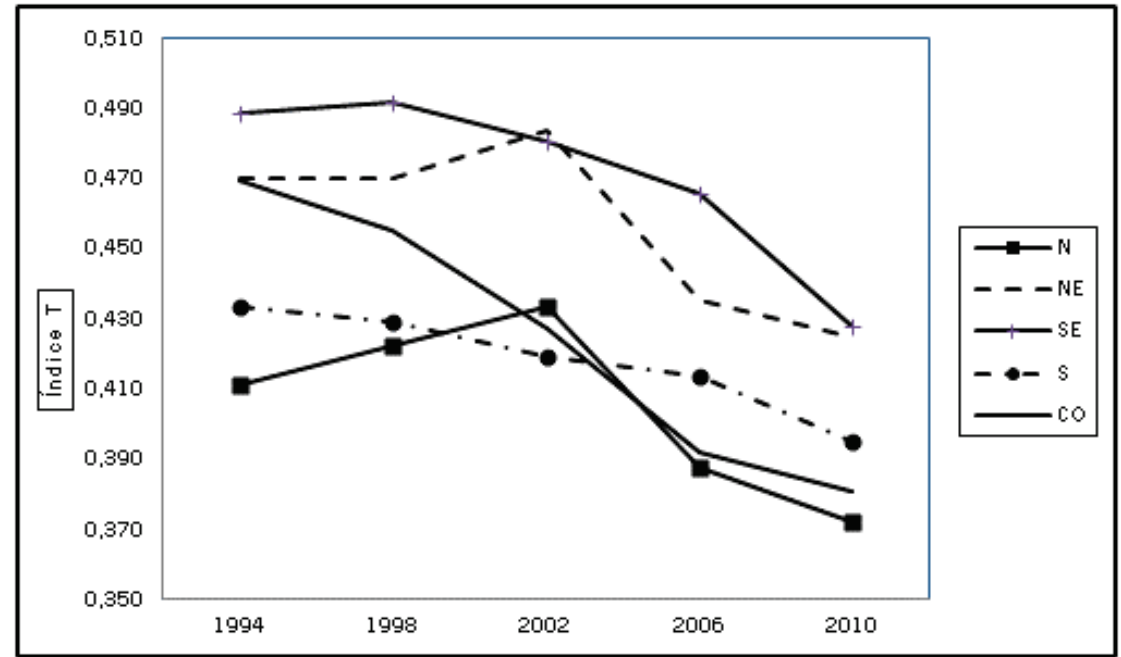

Fonte: Elaboração própria.

O Gráfico 1 mostra que a desconcentração ocorre em todas as regiões. A queda no valor médio do índice se repete, indicando que o aumento de competição ocorre no país inteiro. Ademais, nota-se também que, contrariamente à tese dos grotões, a região sudeste é sistematicamente a menos competitiva, enquanto a norte, a mais. Nas duas primeiras eleições, a região sudeste apresenta valor médio em torno de 0,49, enquanto para a norte, o valor é em torno de 0,42. As duas médias caem ao longo do tempo: na região sudeste, atinge 0,43 em 2010, quando a região norte apresenta valor igual a 0,37. Estes resultados não são obtidos em razão de algum estado em particular dentro destas regiões. Mesmo quando se consideram os resultados por estado individualmente, o comportamento geral é similar. O Gráfico 2 detalha os dados para os estados: 


\section{Gráfico 2}

Evolução das médias do índice T por estado para as cinco eleições

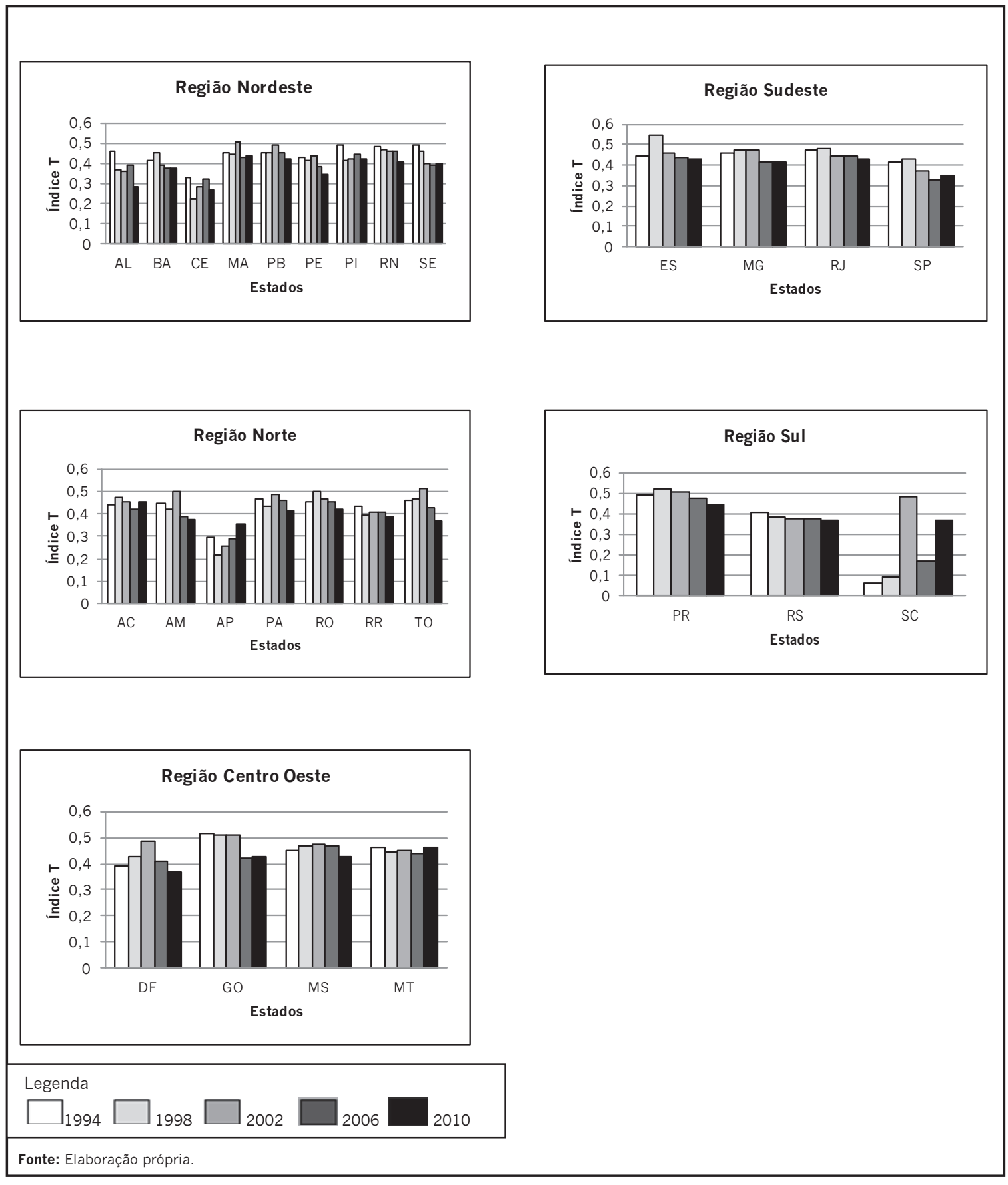


OPINIÃO PÚBLICA, Campinas, vol. 19, n², novembro, 2013, p. 403-429

Com exceção do Amapá, do Acre e de Santa Catarina, em todos os demais estados a eleição de 2010 foi mais competitiva do que a de 1994. Em Alagoas, por exemplo, o índice médio para 2010 era 0,175 pontos menor do que o de 1994. Para a média dos estados, o indicador daquela eleição é 0,056 pontos menor do que em 1994. Cabe mencionar que Santa Catarina é o estado com a menor média geral para as cinco eleições. O valor observado em 1994 era extremamente baixo (igual a 0,063), alcançando o pico em 2002, com 0,486 e, em 2010, atingiu 0,369. Assim, apesar de haver crescimento no indicador entre 1994 e 2010, as eleições neste estado são bastante competitivas de acordo com este critério.

O detalhamento da competição ainda pode ser avaliado ao se comparar os resultados de acordo com o tamanho das populações de cada cidade. Novamente, ao se tomar a ideia de que a dinâmica política nos grotões é distinta, municípios com populações maiores podem apresentar comportamento distinto de cidades pequenas. Além do mais, as capitais, por serem cidades politicamente importantes, podem apresentar valores diferenciados. A Tabela 2 apresenta estes resultados:

Tabela 2

Média do Índice T por tamanho médio de cidades

\begin{tabular}{|l|c|c|c|c|c|}
\hline \multirow{2}{*}{ Porte médio } & \multicolumn{5}{c|}{ Eleições } \\
\cline { 2 - 6 } & 1994 & 1998 & 2002 & 2006 & 2010 \\
\hline Maiores que 200 mil habitantes & 0,406 & 0,393 & 0,386 & 0,393 & 0,390 \\
\hline Entre 50 mil e 200 mil habitantes & 0,494 & 0,493 & 0,459 & 0,475 & 0,470 \\
\hline Menores que 50 mil habitantes & 0,462 & 0,462 & 0,462 & 0,430 & 0,407 \\
\hline Capitais & 0,299 & 0,262 & 0,305 & 0,254 & 0,290 \\
\hline Não capitais & 0,464 & 0,464 & 0,461 & 0,433 & 0,412 \\
\hline
\end{tabular}

Como se pode ver, as cidades de porte intermediário apresentam sistematicamente valores superiores, indicando menor competição eleitoral. Já as cidades maiores de 200 mil habitantes e as cidades pequenas apresentam maior nível de competição. Este resultado sugere que, de acordo com os incentivos para a constituição dos redutos informais, as cidades de porte intermediário tenderiam a ser mais controladas pelos políticos. Esta interpretação é razoável, dado que as cidades menores seriam menos interessantes, já que Ihes trariam menor retorno eleitoral, e as cidades grandes seriam mais difíceis de serem controladas. Mas ainda é uma hipótese a ser verificada. Por outro lado, chama a atenção o fato de as capitais dos estados terem eleições sistematicamente mais competitivas do que as demais cidades. Esta constatação ressalta a importância relativa das cidades: estas não parecem ser igualmente importantes para os políticos, na medida em que os níveis de competição são distintos, seja porque os municípios são mais facilmente controláveis; seja porque há interesse especial em algumas delas, como é os casos das capitais dos estados. Estas avaliações merecem ser aprofundadas, inclusive com avaliações comparativas e ainda considerando características socioeconômicas locais simultaneamente. 


\section{SILVA, G. P. Uma avaliação empírica da competição eleitoral para a Câmara Federal...}

Para esta avaliação, partiu-se para uma análise econométrica em painel com as informações municipais mais pertinentes ao caso, considerando as cinco eleições. A forma funcional geral do modelo é dada pela expressão:

$$
T_{m t}=f\left(\text { Pop }_{m t}, \text { Urb }_{m t}, \text { PIB }_{m t}, \text { Alf }_{m t}, \text { DCapital }_{m t}, \text { Mun }_{\theta t}, \text { Repr }_{\text {et }}, \text { DAno, DRegiao }\right),
$$

onde a variável dependente do modelo é o índice T no município "m" no ano eleitoral "t". Como variáveis independentes, expressas na função acima, foram consideradas as variáveis apresentadas na Tabela 3:

Tabela 3

Estatística descritiva dos dados em painel: 5.564 municípios para 5 eleições

\begin{tabular}{|c|c|c|c|}
\hline Variável & Média & Desvio-Padrão & Medida \\
\hline \multicolumn{4}{|l|}{ Variável dependente } \\
\hline Nível de desequilíbrio $(T)$ & 0,446 & 0,206 & Valor do índice T para cada cidade por eleição \\
\hline \multicolumn{4}{|l|}{ Variáveis Sociais } \\
\hline População (pop) & 32.507 & $192.344,10$ & Contagem populacional para cada cidade \\
\hline Urbanização (urb) & 58,692 & 23,407 & $\begin{array}{l}\text { \% da população municipal que vive em área } \\
\text { urbana }\end{array}$ \\
\hline Alfabetização (alfab) & 77,898 & 14,117 & $\begin{array}{l}\text { \% da população municipal com mais de } 15 \text { anos } \\
\text { que é alfabetizada }\end{array}$ \\
\hline \multicolumn{4}{|l|}{ Variável Econômica } \\
\hline Massa Salarial (sal_real_m) & 968 & $22.419,19$ & $\begin{array}{l}\text { Massa salarial do emprego formal em milhões ( } R \$ \\
\text { de 2012) }\end{array}$ \\
\hline PIB per capita (pibpc) & 4,462 & 5,102 & $\begin{array}{l}\text { PIB municipal em milhares ( } \mathrm{R} \$ \text { de } 2000) \text { dividido } \\
\text { pela população residente }\end{array}$ \\
\hline $\mathrm{PIB}(\mathrm{pib})$ & $239.504,70$ & 2.744 .722 & PIB municipal em milhares ( $\mathrm{R} \$$ de 2000$)$ \\
\hline \multicolumn{4}{|l|}{ Variáveis Políticas } \\
\hline $\begin{array}{l}\text { Representatividade por deputado } \\
\text { (repr) }\end{array}$ & $340.620,20$ & $88.354,20$ & $\begin{array}{l}\text { Relação entre população e número de deputados } \\
\text { eleitos no estado no qual o município se localiza }\end{array}$ \\
\hline $\begin{array}{l}\text { Representatividade por cadeira } \\
\text { (repr_cad) }\end{array}$ & $.4,531$ & 13,612 & $\begin{array}{l}\text { Diferença entre o número de cadeiras em disputa } \\
\text { com aquele que seria justo no caso de uma divisão } \\
\text { das cadeiras do Congresso proporcional à } \\
\text { população de cada estado }\end{array}$ \\
\hline Número de prefeituras (mun) & 382,35 & 249,05 & Número de municípios por estado \\
\hline \multicolumn{4}{|l|}{ Variáveis Regionais } \\
\hline Dummy de capital (capital) & 0,005 & 0,07 & $\begin{array}{l}\text { Dummy igual a } 1 \text { se a cidade é a capital do estado; } \\
0 \text { em caso contrário }\end{array}$ \\
\hline Dummy de região (dreg_) & & & $\begin{array}{l}\text { Dummy igual a } 1 \text { se a cidade pertence à região de } \\
\text { referência; } 0 \text { em caso contrário }\end{array}$ \\
\hline \multicolumn{4}{|l|}{ Variáveis Temporais } \\
\hline Dummy de eleição (d-ano) & & & $\begin{array}{l}\text { Dummy igual a } 1 \text { se os dados se referem à eleição } \\
\text { de referência; } 0 \text { em caso contrário }\end{array}$ \\
\hline \multicolumn{4}{|c|}{$\begin{array}{l}\text { Notas: os dados populacionais utilizados referem-se aos dados do Censo e às contagens realizadas pelo IBGE. Assim, a população considerada } \\
\text { para a eleição de } 1994 \text { é a de } 1991 \text {, para a de } 1998 \text { é a de } 1996 \text {, para a de } 2002 \text { é a de } 2000 \text {, para a de } 2006 \text { é a de } 2007 \text { e para a de } 2010 \text { é a } \\
\text { de } 2010 \text {. O mesmo vale para a taxa de urbanização. Já para a taxa de alfabetização, esta informação existe somente para os anos do Censo. } \\
\text { Assim, esta variável só foi associada às eleições de 1994, } 2002 \text { e } 2010 \text {. O PIB municipal foi calculado pelo IBGE, divulgado pelo IPEA. O valor } \\
\text { utilizado para a eleição de } 1994 \text { é o PIB de 1996; para a eleição de } 1998 \text { é o PIB de 1999; para a de } 2002 \text { e de } 2006 \text { são os dos anos } \\
\text { correspondentes e para a eleição de } 2010 \text { é o de 2009. Para o número de prefeituras, considerou-se o número de cidades nos anos das } \\
\text { contagens populacionais do IBGE. Por fim, para as variáveis estaduais, as estatísticas foram calculadas por estado e não por município. }\end{array}$} \\
\hline
\end{tabular}

Para a definição da forma funcional particular do modelo, foram testadas especificações com o logaritmo e com as formas quadráticas das variáveis ${ }^{9}$. Os resultados das estimativas estão na Tabela $4^{10}$ :

\footnotetext{
${ }^{9}$ Como a correlação entre as variáveis "população" e "PIB" foi igual a 0,957, optou-se por utilizar apenas a primeira variável no modelo.

10 Foram calculados os erros-padrão robustos como forma de corrigir problemas de heteroscedasticidade e da inconsistência testada para os efeitos aleatórios deste modelo. Estes erros-padrão ainda foram corrigidos pela técnica de cluster para os estados da federação.
} 
OPINIÃO PÚBLICA, Campinas, vol. 19, n², novembro, 2013, p. 403-429

Tabela 4

Estimativas dos Parâmetros do Modelo em Painel

\begin{tabular}{|c|c|c|c|c|c|c|}
\hline & (1) & (2) & (3) & (4) & (5) & (6) \\
\hline Variáveis & $\mathrm{T}$ & $\mathrm{T}$ & $T$ & $T$ & $T$ & $T$ \\
\hline \multirow{2}{*}{ população } & $\cdot 2,06 \mathrm{E} \cdot 08$ & $\cdot 3,30 \mathrm{E} \cdot 08$ & $\cdot 7,72 \mathrm{e}-08^{* * *}$ & $-9,91 \mathrm{e} \cdot 08^{* * *}$ & & $\cdot 2,06 \mathrm{E} \cdot 08$ \\
\hline & $(2,58 \mathrm{E} \cdot 08)$ & $(2,60 \mathrm{E} \cdot 08)$ & $(1,73 \mathrm{E} \cdot 08)$ & $(2,04 \mathrm{E} \cdot 08)$ & & $(2,58 \mathrm{E} \cdot 08)$ \\
\hline \multirow[t]{2}{*}{ população ${ }^{2}$} & $1,64 \mathrm{E} \cdot 15$ & $2,63 \mathrm{E} \cdot 15$ & $6,06 \mathrm{e} \cdot 15^{* * *}$ & $7,78 \mathrm{e} \cdot 15^{* * *}$ & & $1,64 \mathrm{E} \cdot 15$ \\
\hline & $(2,10 \mathrm{E} \cdot 15)$ & $(2,34 \mathrm{E} \cdot 15)$ & $(1,65 \mathrm{E} \cdot 15)$ & $(2,12 \mathrm{E} \cdot 15)$ & & $(2,10 \mathrm{E} \cdot 15)$ \\
\hline \multirow[t]{2}{*}{ alfabetização } & 0,001 & & 0,001 & & 0,001 & 0,001 \\
\hline & $(0,002)$ & & $(0,002)$ & & $(0,002)$ & $(0,002)$ \\
\hline \multirow[t]{2}{*}{ alfabetização $^{2}$} & $\cdot 1,30 \mathrm{E} \cdot 05$ & & $\cdot 1,28 \mathrm{E} \cdot 05$ & & $\cdot 1,28 \mathrm{E} \cdot 05$ & $\cdot 1,22 \mathrm{E} \cdot 05$ \\
\hline & $(1,49 \mathrm{E} \cdot 05)$ & & $(1,49 \mathrm{E} \cdot 05)$ & & $(1,46 \mathrm{E} \cdot 05)$ & $(1,47 \mathrm{E} \cdot 05)$ \\
\hline \multirow[t]{2}{*}{ urbanização } & $\cdot 0,0014 * *$ & $.0,0016 * * *$ & $-0,0014 * * *$ & $-0,0017^{* * *}$ & $-0,0013^{* *}$ & $-0,0014 * *$ \\
\hline & $(5,52 \mathrm{E} \cdot 04)$ & $(5,76 \mathrm{E}-04)$ & $(5,46 \mathrm{E} \cdot 04)$ & $(5,73 \mathrm{E} \cdot 04)$ & $(5,27 \mathrm{E} \cdot 04)$ & $(5,55 \mathrm{E} \cdot 04)$ \\
\hline \multirow[t]{2}{*}{ urbanização ${ }^{2}$} & $1,34 \mathrm{e} \cdot 05^{* * *}$ & $1,38 \mathrm{e}-05^{* * *}$ & $1,39 \mathrm{e} \cdot 05^{* * *}$ & $1,47 \mathrm{e} \cdot 05^{* * *}$ & $1,28 \mathrm{e} \cdot 05^{* * *}$ & $1,33 \mathrm{e} \cdot 05^{* * *}$ \\
\hline & $(3,85 \mathrm{E} \cdot 06)$ & $(4,26 \mathrm{E} \cdot 06)$ & $(3,79 E \cdot 06)$ & $(4,23 \mathrm{E} \cdot 06)$ & $(3,56 \mathrm{E} \cdot 06)$ & $(3,87 \mathrm{E} \cdot 06)$ \\
\hline \multirow[t]{2}{*}{ capital } & $0,114 * * *$ & $0,135^{* * *}$ & & & $-0,132^{* * *}$ & $0,114^{* * *}$ \\
\hline & $(0,033)$ & $(0,027)$ & & & $(0,022)$ & $(0,033)$ \\
\hline \multirow[t]{2}{*}{ massa salarial } & & & & & $1,57 \mathrm{e} \cdot 07^{* * *}$ & $1,57 \mathrm{e} \cdot 07^{* * *}$ \\
\hline & & & & & $(3,38 \mathrm{E} \cdot 08)$ & $(3,38 \mathrm{E} \cdot 08)$ \\
\hline \multirow[t]{2}{*}{ número de prefeituras } & $6,74 \mathrm{e} \cdot 05^{* * *}$ & $7,24 \mathrm{e}-05^{* * *}$ & $6,60 \mathrm{e}-05^{* * *}$ & $7,08 \mathrm{e}-05^{* * *}$ & $6,82 \mathrm{e} \cdot 05^{* * *}$ & $6,74 \mathrm{e} \cdot 05^{* * *}$ \\
\hline & $(1,80 \mathrm{E} \cdot 05)$ & $(1,67 \mathrm{E} \cdot 05)$ & $(1,90 \mathrm{E} \cdot 05)$ & $(1,79 \mathrm{E} \cdot 05)$ & $(1,77 \mathrm{E} \cdot 05)$ & $(1,80 \mathrm{E} \cdot 05)$ \\
\hline \multirow[t]{2}{*}{$\begin{array}{l}\text { representatividade por } \\
\text { cadeira }\end{array}$} & $0,0004 * * *$ & $0,0005^{* * *}$ & $0,0004 * * *$ & $0,0005^{* * *}$ & $0,0004 * * *$ & $0,0004 * * *$ \\
\hline & $(1,21 \mathrm{E} \cdot 04)$ & $(1,08 \mathrm{E} \cdot 04)$ & $(1,25 \mathrm{E} \cdot 04)$ & $(1,16 \mathrm{E} \cdot 04)$ & $(1,19 \mathrm{E} \cdot 04)$ & $(1,21 \mathrm{E} \cdot 04)$ \\
\hline \multirow[t]{2}{*}{ dummy_1998 } & & $.0,00393$ & & $.0,0038$ & & \\
\hline & & $\cdot(0,008)$ & & $\cdot(0,008)$ & & \\
\hline \multirow[t]{2}{*}{ dummy_2002 } & 0,001 & $\cdot 0,007$ & 0,001 & $\cdot 0,007$ & 0,002 & 0,001 \\
\hline & $(0,009)$ & $(0,008)$ & $(0,009)$ & $(0,008)$ & $(0,009)$ & $(0,009)$ \\
\hline \multirow[t]{2}{*}{ dummy_2006 } & & $-0,034^{* * *}$ & & $-0,034^{* * *}$ & & \\
\hline & & $(0,007)$ & & $(0,007)$ & & \\
\hline \multirow[t]{2}{*}{ dummy_2010 } & $0,041^{* * *}$ & $-0,055^{* * *}$ & $-0,040 * * *$ & $\cdot 0,054^{* * *}$ & $.0,040^{* * *}$ & $-0,040 * * *$ \\
\hline & $(0,011)$ & $(0,007)$ & $(0,011)$ & $(0,007)$ & $(0,011)$ & $(0,011)$ \\
\hline \multirow[t]{2}{*}{ dummy_região_N } & $.0,035^{* *}$ & $-0,042^{* * *}$ & $-0,036^{* *}$ & $-0,043^{* * *}$ & $.0,034 * *$ & $.0,035^{* *}$ \\
\hline & $(0,015)$ & $(0,011)$ & $(0,015)$ & $(0,011)$ & $(0,015)$ & $(0,015)$ \\
\hline \multirow[t]{2}{*}{ dummy_região_CO } & $\cdot 0,017$ & $-0,030 * * *$ & $\cdot 0,018$ & $\cdot 0,031^{* * *}$ & $-0,017$ & $.0,018$ \\
\hline & $(0,013)$ & $(0,010)$ & $(0,013)$ & $(0,010)$ & $(0,013)$ & $(0,013)$ \\
\hline \multirow[t]{2}{*}{ dummy_região_SE } & 0,0004 & $.0,011$ & 0,002 & $\cdot 0,010$ & 0,0004 & 0,0003 \\
\hline & $(0,015)$ & $(0,008)$ & $(0,016)$ & $(0,009)$ & $(0,015)$ & $(0,015)$ \\
\hline \multirow[t]{2}{*}{ dummy_região_S } & $\cdot 0,030$ & $-0,053^{* * *}$ & $.0,029$ & $-0,053^{* * *}$ & $.0,030$ & $.0,030$ \\
\hline & $(0,026)$ & $(0,019)$ & $(0,026)$ & $(0,019)$ & $(0,025)$ & $(0,026)$ \\
\hline \multirow[t]{2}{*}{ Constant } & $0,492^{* * *}$ & $0,499 * * *$ & $0,496 * * *$ & $0,503^{* * *}$ & $0,492^{* * *}$ & $0,495^{* * *}$ \\
\hline & $(0,065)$ & $(0,018)$ & $(0,064)$ & $(0,018)$ & $(0,063)$ & $(0,065)$ \\
\hline Observações & 15.559 & 26.098 & 15.559 & 26.098 & 15.559 & 15.559 \\
\hline Números de Grupos & 5.563 & 5.564 & 5.563 & 5.564 & 5.563 & 5.563 \\
\hline
\end{tabular}




\section{SILVA, G. P. Uma avaliação empírica da competição eleitoral para a Câmara Federal ...}

Os resultados mostram que o tamanho e o nível de alfabetização da população não são fatores correlacionados ao nível de competitividade eleitoral nos municípios brasileiros. Deve-se notar, aliás, que a dummy para a capital rouba todo o efeito observado para o tamanho das cidades: a diferença entre os modelos 1 e 3 e os modelos 2 e 4 é simplesmente a adição desta dummy, cujos níveis de competição são mais elevados que das demais cidades. Sua introdução faz com que o tamanho relativo das cidades perca significância estatística. Com a elevada correlação entre a variável de população e o PIB municipal, a análise é válida para o aspecto econômico também: o valor da renda municipal não tem correlação com o nível de competição eleitoral municipal. Sobre o aspecto econômico, vale ressaltar que o PIB per capita também não apresenta correlação estatisticamente significante com a competição eleitoral. A única variável econômica que apresenta significância é a massa de salário do emprego formal: quanto maior seu valor, menor a competitividade. Porém, a significância estatística desta variável não se mantém quando se faz testes de robustez (vide nota 10). Outros fatores ganham, assim, importância. 0 nível de urbanização é estatisticamente significante: quanto maior o percentual de pessoas vivendo na área urbana da cidade, maior o nível de competição. Como a variável quadrática também é significativa, a relação entre estes conceitos é decrescente, mas a taxas crescentes. Chama atenção também a variável que considera o número de municípios. Ela indica que, quanto maior o número de municípios no estado, menos competitiva é a eleição para deputado federal nas cidades. Ou seja, quanto maior o número de prefeitos potencialmente participando da eleição, menor a competitividade. Ainda que seja necessário aprofundar sua interpretação, este resultado estaria de acordo com os trabalhos sobre a relação entre prefeitos e as eleições para deputado já citados. A variável que mede representatividade também é relevante para a explicação do nível de competição eleitoral: quanto maior a representatividade, menor a competição. Deve-se ressaltar, porém, que apenas a variável de representatividade por cadeira mostrou-se estatisticamente significante. Isto sugere que o número de representantes por deputado não é fator importante para o nível de disputa eleitoral em uma cidade, mas a sobrerrepresentação, sim. As dummies de ano confirmam a interpretação da Tabela 1: as eleições de 2006 e 2010 foram mais competitivas do que as demais, enquanto as outras três apresentaram níveis idênticos. Quanto às regiões, observa-se que a região norte é mais competitiva que a região nordeste e que esta tem nível semelhante à região sudeste. Sobre as regiões sul e centro-oeste, o resultado é inconclusivo, pois, ao se considerar o nível de alfabetização no modelo, o efeito das dummies regionais desaparece. Entretanto, esta observação pode decorrer da redução no número de observações nestes $\operatorname{casos}^{11}$.

Além dos importantes resultados encontrados, ainda resta avaliar a outra dimensão da competição que recai sobre a permanência de um indivíduo como líder local. Para isso, a Tabela 5 apresenta os resultados da votação individual em cada cidade. O objetivo é verificar se os indivíduos têm capacidade de evitar a concorrência e, assim, reduzir a competição local.

11 Foram estimados os parâmetros do modelo em que a variável T sofreu transformações da forma $\ln (\mathrm{T} / 1$ - $\mathrm{T})$ e em que foram consideradas apenas as observações restritas para o intervalo em que $0,3<T<0,7$. Não houve alteração nos resultados apresentados, salvo a perda de significância da variável de massa salarial, representatividade por cadeira e as dummies regionais, no caso da restrição de valores. 
OPINIÃO PÚBLICA, Campinas, vol. 19, n², novembro, 2013, p. 403-429

Tabela 5

Descrição do Número de Candidatos Votados por Cidade por Eleição

\begin{tabular}{|l|c|c|c|c|c|}
\hline & 1994 & 1998 & 2002 & 2006 & 2010 \\
\hline Média & 77 & 77 & 96 & 110 & 105 \\
\hline Desvio Padrão & 74 & 79 & 85 & 111 & 112 \\
\hline Mínimo & 8 & 5 & 12 & 16 & 11 \\
\hline Máximo & 525 & 661 & 724 & 1.007 & 1.168 \\
\hline Mediana & 56 & 54 & 71 & 77 & 72 \\
\hline $1^{\circ}$ Quartil & 36 & 37 & 50 & 52 & 48 \\
\hline $3^{\circ}$ Quartil & 89 & 84 & 106 & 120 & 113 \\
\hline
\end{tabular}

A Tabela 5 mostra um número médio relativamente elevado de candidatos a receber votos em uma cidade: 77, em média, entre 1994 e 1998, valor que se eleva ao longo do tempo, atingindo 104 em 2010. Deve-se lembrar que, se o número de candidatos a receber votos em uma mesma cidade aumenta, o índice T tende a se elevar, mantido o patamar de votos do candidato mais bem colocado. Como de fato os resultados anteriores indicam que o índice $T$ reduziu-se, pode-se inferir que, em média, o candidato mais bem colocado nas eleições em cada cidade recebeu número menor de votos ao longo do tempo. Ou seja, estas informações indicam queda na capacidade do político com maior número de votos em evitar a concorrência. Outra observação importante é que todos os valores na Tabela 5 cresceram até 2006, sendo que, em 2010, os números se aproximam aos de 2002, sugerindo um acomodamento nestes níveis superiores ao de 1994 e 1998. Uma informação também relevante é a de que nenhuma cidade do país votou em menos do que cinco nomes distintos (eleição de 1998) e, nas últimas três eleições, em menos do que onze nomes. Isto enfraquece a imagem de que um indivíduo apenas é capaz de angariar a grande maioria dos votos em uma cidade. Estas informações sugerem que não se pode falar sobre a capacidade dos deputados em consolidar suas áreas de influência através das barreiras a outros candidatos. Os municípios parecem ser disputados, ao menos pelo número de candidatos que conseguem votos ali. Também chama atenção a variabilidade dos resultados. A ausência de competição não é estável temporalmente.

A ideia de consolidação de uma zona de influência para a estabilidade do deputado em seu cargo pressupõe, evidentemente, que o indivíduo busque se reeleger. Mais do que isto, a interpretação tradicional afirma que o deputado obtém sucesso neste intento. Para verificar esta condição, a Tabela 6 apresenta o número de parlamentares eleitos em determinado pleito que permanecem em legislaturas posteriores: 
SILVA, G. P. Uma avaliação empírica da competição eleitoral para a Câmara Federal...

Tabela 6

Histórico da Permanência dos Deputados Titulares por Legislatura

\begin{tabular}{|c|c|c|c|c|c|}
\hline \multirow{2}{*}{ Eleitos em } & \multicolumn{5}{l}{ Reelegeram.se em } \\
\cline { 2 - 6 } & 1994 & 1998 & 2002 & 2006 & 2010 \\
\hline 1990 & 217 & 148 & 96 & 71 & 44 \\
\hline 1994 & & 269 & 179 & 126 & 80 \\
\hline 1998 & & & 268 & 167 & 114 \\
\hline 2002 & & & & 260 & 170 \\
\hline 2006 & & & & & 283 \\
\hline
\end{tabular}

Nota-se claramente que o número de parlamentares que permanecem no cargo é decrescente ao longo do tempo. Cerca de $60 \%$ dos eleitos em uma eleição estarão na legislatura seguinte. Por exemplo, dos 503 deputados eleitos em 1990, apenas 217 (43\%) se reelegeram em 1994. O número reduz-se em cada legislatura, até que, em 2010, haja apenas 44 deles ${ }^{12}$. Também chama atenção a existência de um padrão no número de deputados que obtêm sucesso no pleito seguinte. O número de parlamentares que se reelegem do primeiro para o segundo ano é da ordem de $50 \%$, com exceção de 1990-94. Depois, para cada ano, reduz-se em cerca de 35\%, em média, o número de deputados que estavam na legislatura de referência.

Apesar destas evidências enfraquecerem o argumento de que os parlamentares conseguiriam manter-se no cargo, gerando um padrão de carreira estática, cabe ainda verificar se a estratégia de eliminar a competição em uma localidade leva ao sucesso eleitoral. Para estas avaliações, uma relação de cidades foi tomada para análise detalhada. Optou-se por cidades cujos valores de desequilíbrio estivessem no quartil mais elevado em, ao menos, quatro eleições ${ }^{13}$, formando o grupo de municípios de baixa competição eleitoral. Neste corte, há 177 municípios, representando apenas 3,2\% dos 5.567 em 2010. Este número ainda representa $12,7 \%$ das cidades constantes no último quartil daquele ano, número baixo, sugerindo variação na disputa observada em diferentes eleições. Cabe também observar que apenas 36 cidades brasileiras apresentaram valor de competição neste quartil nas cinco eleições, reforçando a compreensão sobre a ausência de controle estável dos resultados anteriores. Foram observados os dados eleitorais em cada uma destas 177 cidades e avaliados o grau de sucesso do candidato mais votado nestes municípios e o número de pessoas diferentes que alcançaram a posição de mais votados ao longo do tempo. A Tabela 7 contém as informações:

\footnotetext{
12 Ou seja, em 2010, há apenas 44 parlamentares com seis mandatos consecutivos no Congresso Nacional.

13 Foram feitas as mesmas análises com o grupo de cidades que esteve neste quartil em pelo menos em três ocasiões. Ainda que o número de cidades tenha aumentado, a análise substantiva não se alterou.
} 


\section{Tabela 7}

Histórico do Desequilíbrio Eleitoral e o Sucesso Individual na Eleição

\begin{tabular}{|c|c|c|c|c|c|c|c|c|}
\hline \multirow{2}{*}{$\begin{array}{c}\text { Número de } \\
\text { candidatos } \\
\text { diferentes a obter o } \\
\text { maior número de } \\
\text { votos }\end{array}$} & \multicolumn{8}{|c|}{ Número de vezes em que o candidato de maior votação na cidade se elegeu } \\
\hline & 0 & 1 & 2 & 3 & 4 & 5 & Total & Percentual \\
\hline 1 & 0 & 2 & 2 & 13 & 4 & 0 & 21 & 11,86 \\
\hline 2 & 1 & 3 & 7 & 21 & 17 & 3 & 52 & 29,38 \\
\hline 3 & 1 & 5 & 7 & 19 & 15 & 3 & 50 & 28,25 \\
\hline 4 & 2 & 5 & 10 & 11 & 12 & 0 & 40 & 22,60 \\
\hline 5 & 1 & 1 & 2 & 5 & 5 & 0 & 14 & 7,91 \\
\hline Total & 5 & 16 & 28 & 69 & 53 & 6 & 177 & \\
\hline Percentual & $2,82 \%$ & $9,04 \%$ & $15,82 \%$ & $38,98 \%$ & $29,94 \%$ & $3,39 \%$ & & \\
\hline
\end{tabular}

Fonte: Elaboração própria a partir de dados do TSE.

Os dados indicam que, em 21 cidades não competitivas, houve apenas um mesmo candidato mais votado ao longo das cinco eleições. Porém, em nenhum caso, este se elegeu em todas as eleições; em treze cidades, este político mais votado elegeu-se três vezes. Por outro lado, em 50 cidades não competitivas, houve três políticos diferentes que foram os mais votados. Em três vezes, o mais votado elegeu-se nas cinco eleições. Chama atenção que, em cerca de $69 \%$ dos casos, o indivíduo mais votado em uma cidade elegeu-se em 3 ou em 4 pleitos. Isto sugere que conseguir muitos votos em uma cidade contribui para que o indivíduo se eleja, mas não há garantias de sucesso. Haveria outros fatores que influenciariam este resultado. Mais interessante no contexto deste estudo é que, em pouco mais de $59 \%$ dos casos, três ou mais políticos diferentes ao longo das cinco eleições tornaram-se os mais votados em cidades consideradas não competitivas. Esta informação sugere que, assim como os indicadores de desequilíbrio, os resultados de uma eleição são circunstanciais, sem evidências de que perdurarão ao longo do tempo, formando uma base de controle estável. Novamente, não parece corresponder aos dados a ideia que se faz sobre a dinâmica política dos grotões. Ao contrário, os dados em conjunto parecem sugerir que há alternância no posto de mais bem colocado no resultado eleitoral de uma cidade ou, ainda, que, na verdade, há um grupo de políticos que atuam como referência política nas diversas regiões de um estado. Isto pode ser ilustrado através do exemplo da Tabela 8 , que apresenta os resultados eleitorais da cidade de Santos, situada no litoral paulista: 
SILVA, G. P. Uma avaliação empírica da competição eleitoral para a Câmara Federal...

Tabela 8

Detalhamento das Eleições para Santos - SP

\begin{tabular}{|c|c|c|c|c|c|c|}
\hline \multicolumn{2}{|c|}{ Informações } & 1994 & 1998 & 2002 & 2006 & 2010 \\
\hline \multicolumn{2}{|c|}{ Índice T } & 0,432 & 0,566 & 0,343 & 0,249 & 0,207 \\
\hline \multicolumn{2}{|c|}{ Número de candidatos que receberam votos } & 478 & 557 & 562 & 773 & 862 \\
\hline \multicolumn{2}{|c|}{ Total de votos nominais } & 203.339 & 214.939 & 256.502 & 216.728 & 214.836 \\
\hline \multicolumn{2}{|c|}{ Percentual de votos recebido pelo 10.} & $35,1 \%$ & $38,4 \%$ & $32,3 \%$ & $21,1 \%$ & $15,3 \%$ \\
\hline \multicolumn{2}{|c|}{ Percentual de votos recebido pelos cinco 1 os. } & $81,3 \%$ & $72,2 \%$ & $77,6 \%$ & $67,4 \%$ & $55,4 \%$ \\
\hline \multicolumn{7}{|c|}{ Principais candidatos } \\
\hline \multirow{5}{*}{ Paulo Roberto Mansur } & Candidatou-se & $\operatorname{sim}$ & não & não & $\operatorname{sim}$ & $\operatorname{sim}$ \\
\hline & Elegeu-se & $\operatorname{sim}$ & não & não & sim & sim \\
\hline & Votos Totais & 86.711 & . & . & 67.447 & 65.397 \\
\hline & Votos em Santos & 29.093 & . & . & 34.969 & 32.855 \\
\hline & Posição na cidade & 30. & & & 20. & 10. \\
\hline \multirow{5}{*}{ Telma de Souza } & Candidatou-se & $\operatorname{sim}$ & sim & sim & $\operatorname{sim}$ & não \\
\hline & Elegeu-se & $\operatorname{sim}$ & $\operatorname{sim}$ & $\operatorname{sim}$ & não & não \\
\hline & Votos Totais & 138.083 & 135.172 & 161.198 & 89.637 & . \\
\hline & Votos em Santos & 71.466 & 82.590 & 82.795 & 45.632 & . \\
\hline & Posição na cidade & 10. & 10. & 10. & 10. & . \\
\hline \multirow{5}{*}{ Vicente Cascione } & Candidatou-se & $\operatorname{sim}$ & $\operatorname{sim}$ & $\operatorname{sim}$ & $\operatorname{sim}$ & $\operatorname{sim}$ \\
\hline & Elegeu-se & $\operatorname{sim}$ & não & $\operatorname{sim}$ & não & não \\
\hline & Votos Totais & 53.178 & 55.602 & 108.094 & 28.728 & 45.276 \\
\hline & Votos em Santos & 42.539 & 42.123 & 61.656 & 14.261 & 25.503 \\
\hline & Posição na cidade & 20. & 20. & 20. & 50. & 20. \\
\hline
\end{tabular}

Fonte: Elaboração própria a partir de dados do TSE.

Nesta cidade, os políticos Vicente Cascione, Paulo Mansur e Telma de Souza disputam sistematicamente os votos em diferentes eleições. Os dois últimos alternam a disputa pelos cargos de deputado federal e prefeito ${ }^{14}$. Para o caso de interesse aqui, eventualmente, apenas um deles concorre a deputado federal e é esperado que obtenha percentual elevado de votos nas cidades da região. O que se observa na Tabela 8, em primeiro lugar, é a contínua redução dos valores obtidos pelo índice T ao longo dos anos, repetindo o comportamento nacional. Ao mesmo tempo, o número de candidatos que obtêm votos naquela cidade é crescente, também de maneira idêntica aos resultados para o país. Estes

14 Em 1989, Telma de Souza elege-se prefeita em Santos e faz seu sucessor, David Capistrano Filho em 1992. Durante o mandato de Telma, Paulo Mansur exerce o cargo de vereador na cidade. Na eleição de 1996, Telma de Souza vence o primeiro turno, mas Paulo Mansur se elege na disputa em segundo turno. Em 2000, a situação se repete com Telma vencendo o primeiro turno, mas perdendo a eleição para Paulo Mansur. Em 2004, novamente, Telma vence no primeiro turno, mas perde a eleição no segundo turno, agora para João Paulo Papa. 
números encontram correspondência com a redução do percentual obtido pelo candidato mais votado: parte de 35\% para 15\% até 2010. O mesmo se dá com relação ao percentual obtido pelos cinco mais bem votados: de 81\% em 1994 para 55\% em 2010. Chama atenção que, dentre os candidatos mais bem votados, estão sistematicamente os mesmos indivíduos: Paulo Roberto Mansur, Telma de Souza e Vicente Cascione. Os dois primeiros já foram prefeitos da cidade e são figuras políticas de destaque local. Porém, como pode ser visto, eles não saem simultaneamente como candidatos em todos os pleitos. E ainda, nem todos eles se elegem uma vez que concorram. Ou seja, o resultado observado em um pleito específico camufla a disputa política que efetivamente estes três travam na região. 0 fato de apenas um deles lançar-se candidato a deputado federal não implica na ausência dos demais como figuras políticas relevantes. Ainda que apenas um seja eleito, não parece refletir a real disputa política local afirmar que o eleito consiga evitar a competição ao longo do tempo. Apesar dos incentivos eleitorais, o contexto parece mais complexo.

\section{Considerações Finais}

Este artigo discutiu empiricamente a competição eleitoral nos pleitos proporcionais no Brasil e ofereceu dados consistentes para refutar as teses existentes de que o sistema político brasileiro se organiza em distritos eleitorais informais, nas suas dimensões relativas quanto ao nível de disputa eleitoral observada nas cidades brasileiras e na capacidade do indivíduo em permanecer como referência política única nas disputas para o cargo de deputado federal nos municípios.

Os valores de desequilíbrio são relativamente baixos para se afirmar que a ausência de competição é a regra. Observa-se que os níveis efetivos de competição vêm se elevando desde 1994. As capitais mostram-se mais competitivas do que as demais cidades e a taxa de urbanização dos municípios é fator indicativo de elevação no nível de competição das localidades. Porém, nem o nível de alfabetização, nem os tamanhos das populações mostraram-se fatores explicativos da competição. 0 mesmo vale para as variáveis econômicas, medidas pelo PIB e PIB per capita. Estas não se mostraram significativas. A massa salarial do emprego formal, ao contrário do esperado, mostrou-se favorável à redução da competitividade, o que contraria as ideias associadas à teoria da modernização. As regiões nordeste e sudeste mostraram-se aquelas com menores níveis de competição em relação às demais. Ainda, o número de prefeitos presentes no estado interfere na competição: quanto maior seu número, menor é a competição. 0 mesmo resultado é válido com relação à representatividade mensurada pelo número de cadeiras em disputa: quanto mais sobrerrepresentado for o estado, menor o nível de competição eleitoral.

Ademais, a ideia de que os políticos conseguem evitar a competição em uma determinada localidade, que pressupõe a sua manutenção na disputa como deputado federal, não parece ter correspondência empírica. Os deputados não se reelegem sistematicamente, nem o desequilíbrio em determinada cidade é suficiente para que consigam se eleger. Torna-se necessário investigar os padrões de carreira dos políticos, mas há fortes evidências de que transitam entre diferentes cargos, como de secretários de governo ou ainda de prefeito, em que o componente regional é importante, mas que abre espaço para que outros políticos disputem o poder local. 


\section{SILVA, G. P. Uma avaliação empírica da competição eleitoral para a Câmara Federal...}

Uma análise necessária é verificar estes resultados considerando os votos de legenda, brancos e nulos. Em diversas cidades, estes últimos acabam por gerar desequilíbrio, sugerindo ausência na preferência por algum político na cidade. Em outras, as legendas partidárias encontram-se como um destino importante dos votos dos eleitores. A teoria tradicional não permite que se interprete esses resultados, já que recai sobre a votação individual, mas estas informações não podem ser negligenciadas.

Por fim, um aspecto que deve ser enfatizado é a intencionalidade da competição. Os candidatos buscarão votos em determinadas áreas de acordo com suas características individuais e dos municípios. Mas também a disputa política dependerá da capacidade do partido de selecionar candidatos que não disputem votos nas mesmas regiões do distrito. O papel dos partidos e das coligações feitas não foi considerado, mas merece atenção neste tema.

\section{Referências Bibliográficas}

AmES, B. "Electoral Strategy under Open-List Proportional Representation". American Journal of Political Science, 39, p. $406 \cdot 33,1995 a$

"Electoral Rules, Constituency Pressures, and Pork Barrel: Bases of Voting in Brazilian Congress." The Journal $\overline{\text { of Politics, }}$ 57, p. 324.43, 1995b.

The Deadlock of Democracy in Brazil. Ann Arbor: The University of Michigan Press, 2001.

2003.

Os Entraves da Democracia no Brasil. Tradução de Vera Pereira. Rio de Janeiro: Fundação Getúlio Vargas,

Amorim Neto, O.; Cox, G. W. "Electoral Institutions, Cleavage Structures, and the Number of Parties". American Journal of Political Science, vol. 41, n 1, p. 149.174, 1997.

Avelino, G.; Biderman, C.; BARONE, L. S. "Articulações intrapartidárias e desempenho eleitoral no Brasil". Dados - Revista de Ciências Sociais, 49, n² 2, p. 319.347, 2011.

Revista de Ciências Sociais, 55, n 4, p. 987-1013, 2012.

Braga, M. S. S. O processo partidário-eleitoral brasileiro: padrões de competição política (1982-2002). São Paulo: Associação Editorial Humanitas, Fapesp, 2006.

Cain, B.; Ferejohn, J.; FIORINA, M. The Personal Vote. Constituency Service and Electoral Independence. Cambridge, Massachusetts: Harvard University Press, 1987.

CAmpello, D.; Zucco, C. A esquerda em um país democrático, globalizado e desigual: uma análise do Brasil de Lula. In: Moreira, C. et al (orgs.). Perspectivas Analiticas Sobre Nuevos Gobiernos y Sociedad en America Latina. Montevideo: Trilice, 2008.

Caramani, D. "The End of Silent Elections. The Birth of Electoral Competition, 1832-1915." Party Politics, 9 (4), p. $411.443,2003$

CAREY, J.; SHUGART, M. “Incentives to cultivate a personal vote.” Electoral Studies, 14 (4), p. 417.439, 1995.

CARneIRo, L.; Almeida, M. H. T. "Definindo a arena política local: sistemas partidários municipais na federação brasileira”. Dados - Revista de Ciências Sociais, 51 (2), p. 403-432, 2008.

CRISP, B.; Desposato, S. "Constituency Building in Multimember Districts: Collusion or Conflict?" The Journal of Politics, 66 (1), p. $136 \cdot 156,2004$.

Crisp, B.; JenSEN, K. E Shomer, Y. "Magnitude and vote seeking”. Electoral Studies, 26, p. 727.734, 2007. 
OPINIÃO PÚBLICA, Campinas, vol. 19, n², novembro, 2013, p. 403-429

DuVERger, M. Les partis politiques. 2. ed. (rev. et mise a jour). Paris: Ed. A. Colin, 1951.

FiguelRedo, A.; LIMongl, F. “Incentivos Eleitorais, Partidos e Política Orçamentária." Dados - Revista de Ciências Sociais, 45 (2), p. 303-344, 2002.

. Política Orçamentária no Presidencialismo de Coalizão. Rio de Janeiro: Ed. FGV, 2008.

Holbrook, T.; Von Dunk, E. "Electoral Competition in American States." American Political Science Review, 87 (4), p. $955 \cdot 962,1993$.

Hunter, W.; Power, T. "Rewarding Lula: Executive Power, Social Policy, and the Brazilian Elections of 2006." Latin American Politics and Society, 49 (1), p. 1-30, 2007.

JACOB, C. R. et al. "A eleição presidencial de 2006 no Brasil: continuidade política e mudança na geografia eleitoral". Alceu, 10 (9), p. 232.261, 2009.

KInZO, M. D.; MARTINS, J. P.; BoRIN, I. "Patrones de Competencia Electoral en la Disputa por la Cámara de Diputados en Brasil (1994-2002)." América Latina Hoy, 38, p. 143-162, 2004.

LAMOUNIER, B. "Authoritarian Brazil Revisited: The Impact of Elections on the Abertura". In: STEPAN, A. (org.). Democratizing Brazil: Problems of Transition and Consolidation. Oxford: Oxford University Press, 1989.

LIJPHART, A. "The Political Consequences of Electoral Laws, 1945-85". The American Political Science Review, 84 (2), p. 481.496, 1990.

LIMONGI, F. “A democracia no Brasil. Presidencialismo, coalizão partidária e processo decisório”. Novos EstudosCEBRAP, São Paulo, n. 76, 2006.

MaInwaring, S. "Politicians, Parties, and Electoral Systems: Brazil in Comparative Perspective." Comparative Politics, 24 (1), p. 21.43, 1991.

Marenco Dos Santos, A. "Nas fronteiras do campo político: raposas e outsiders no Congresso Nacional". Revista Brasileira de Ciências Sociais, 12, 33, p. 87-101, 1997.

MAYHEW, D. Congress: The Electoral Connection. New Haven: Yale University Press, 1974

Melo, C. R. "As instituições políticas brasileiras funcionam?" Revista Brasileira de Sociologia e Política, n²5, p. 247-250, 2005 .

Montero, A. P. "No Country for Leftists? Clientelist Continuity and the 2006 Vote in the Brazilian Northeast". Journal of Politics in Latin America, 2 (2), p. 113.153, 2010.

Nicolau, J. "O Sistema Eleitoral de Lista Aberta no Brasil." Dados - Revista de Ciências Sociais, 49 (4), p. 689.720, 2006.

Pereira, C.; Rennó, L. "O que é que o reeleito tem? Dinâmicas político-institucionais locais e nacionais nas eleições de 1998 para a Câmara dos Deputados.". Disponível em: <http://www.scielo.br/scielo.php?script=sci_arttext\&pid=S0011. $52582001000200004 \&$ Ing=pt\&nrm=iso $>$. Dados, 44, (2), 2001.

QueRALT, D. "Learning the Mechanical Effect of Electoral Systems". Working Paper Series, Center for Advanced Study in Social Sciences, Working Paper 2009/ 241, 2009.

RAE, D. The Political Consequences of Electoral Laws. New Haven: Yale University Press, 1967.

Samuels, D. "Incentives to Cultivate a Party Vote in Candidate-centric Electoral Systems." Comparative Political Studies, $32(4)$, p. $487 \cdot 518,1999$.

“Ambition and Competition: Explaining Legislative Turnover in Brazil." Legislative Studies Quarterly, 25 (3), p. $481.497,2000$.

Ambition, Federalism, and Legislative Politics in Brazil. Cambridge: Cambridge University Press, 2003.

SANTOS, F. "Brazilian democracy and the power of 'old' theories of party competition". Brazilian Political Science Review (online), 3: 0-0, 2008

SANTOS, W. G. "Grotões e coronéis vivem de estatística". Valor Econômico, São Paulo, 15 dez. 2006.

Schofield, N.; MARTin, A.; Quinn, K.; Whitford, A. "Multiparty electoral competition in the Netherlands and Germany: A model based on multinomial probit". Public Choice, 97, p. 257-293, 1998. 
SILVA, G. P. Uma avaliação empírica da competição eleitoral para a Câmara Federal...

SoAREs, G. A. D.; TerRon, S. L. "Dois Lulas: a geografia eleitoral da reeleição (explorando conceitos, métodos e técnicas de análise geoespacial)". Opinião Pública, n 14, vol. 2, p. 269-301, 2008.

TAagepera, R. "Inequality, Concentration, Imbalance". Political Methodology, 275-91, 1979.

Velho, O. G. Entrevista: O fim dos Grotões. Carta Capital, 420, p. 28-30, 22 de nov. 2006.

Zucco, C. "The President's 'New' Constituency: Lula and the Pragmatic Vote in Brazil's 2006 Presidential Elections." Journal of Latin American Studies, 40, p. 29.49, 2008.

Apêndice 1

Simulações de Diferentes Resultados Eleitorais por Cidade para o Índice T (em \%)

\begin{tabular}{|c|c|c|c|c|c|}
\hline \multicolumn{6}{|c|}{ Caso 1 - Concentração dos votos em torno do $2^{\circ}$ lugar } \\
\hline$(\%)$ & Eleição 1 & Eleição 2 & Eleição 3 & Eleição 4 & Eleição 5 \\
\hline Candidato 1 & 60 & 60 & 60 & 60 & 60 \\
\hline Candidato 2 & 20 & 25 & 30 & 35 & 40 \\
\hline Candidato 3 & 10 & 10 & 10 & 5 & \\
\hline Candidato 4 & $10 \times 1$ & $5 \times 1$ & & & \\
\hline $\mathbf{T}$ & 0,6605 & 0,5712 & 0,4752 & 0,3934 & 0,2875 \\
\hline \multicolumn{6}{|c|}{ Caso 2 - Desconcentração dos votos do $2^{\circ}$ lugar } \\
\hline$(\%)$ & Eleição 1 & Eleição 2 & Eleição 3 & Eleição 4 & Eleição 5 \\
\hline Candidato 1 & 75 & 75 & 75 & 75 & 75 \\
\hline Candidato 2 & 25 & 20 & 20 & $2 \times 10$ & $3 \times 5$ \\
\hline Candidato 3 & & 5 & $2 \times 2$ & $2 \times 2$ & $4 \times 2$ \\
\hline Candidato 4 & & & 1 & 1 & $2 \times 1$ \\
\hline $\mathbf{T}$ & 0,5860 & 0,6694 & 0,6795 & 0,8029 & 0,8973 \\
\hline \multicolumn{6}{|c|}{ Caso 3 - Desconcentração de votos do $1^{\circ}$ para o $3^{\circ}$ lugar } \\
\hline$(\%)$ & Eleição 1 & Eleição 2 & Eleição 3 & Eleição 4 & Eleição 5 \\
\hline Candidato 1 & 50 & 40 & 30 & 30 & $3 \times 25$ \\
\hline Candidato 2 & $2 \times 25$ & $2 \times 25$ & $2 \times 25$ & $2 \times 25$ & $2 \times 10$ \\
\hline Candidato 3 & & 10 & $2 \times 10$ & 20 & 5 \\
\hline $\mathbf{T}$ & 0,4085 & 0,3208 & 0,1508 & 0,1174 & 0,0585 \\
\hline \multicolumn{6}{|c|}{ Caso 4 - Desconcentração de votos do $1^{\circ}$ para os demais } \\
\hline$(\%)$ & Eleição 1 & Eleição 2 & Eleição 3 & Eleição 4 & Eleição 5 \\
\hline Candidato 1 & 80 & 70 & 60 & 50 & 30 \\
\hline Candidato 2 & $2 \times 10$ & 20 & 20 & 20 & $2 \times 15$ \\
\hline Candidato 3 & & 10 & $2 \times 10$ & $3 \times 10$ & $4 \times 10$ \\
\hline $\mathbf{T}$ & 0,7902 & 0,6582 & 0,6331 & 0,5776 & 0,3366 \\
\hline
\end{tabular}


No Caso 1 , os votos na eleição 1 se dividem em $60 \%$ para o primeiro candidato, $20 \%$ para o segundo, $10 \%$ para o terceiro e dez candidatos obtêm $1 \%$ cada. 0 indicador T nesse caso atinge 0,6605, um valor relativamente alto, indicando alguma ausência de competição. Na medida em que se observa uma concentração dos votos dos demais candidatos em torno do segundo lugar ao longo das eleições, o índice T vai reduzindo seu valor. Ele atinge 0,2875 no contexto em que os votos estão divididos em apenas dois candidatos, o primeiro com $60 \%$ e o segundo com $40 \%$ do total, indicando haver alguma competição nesta cidade. No caso dois, os votos do segundo candidato mais votado vão se transferindo para os demais e os votos do primeiro lugar permanecem estáveis. Neste contexto, o índice T vai aumentando gradativamente. No caso, sai de 0,586 para 0,8973, ressaltando a importância das disputas não só pelo primeiro lugar. No terceiro caso, os votos do candidato mais votado se transferem para o terceiro mais votado, mantidos os votos do segundo lugar. Neste cenário, o índice $T$ reduz-se acentuadamente. Na primeira eleição simulada, quando o mais votado obtém metade dos votos e o restante é dividido entre dois candidatos, o índice é igual a 0,4085. A medida em que os votos do primeiro colocado se transferem para o terceiro lugar, o índice vai se reduzindo, até atingir 0,0585, quando seus votos se igualam aos seguintes em $25 \%$. Por fim, no quarto caso, os votos do primeiro colocado reduzem-se gradativamente, enquanto os do terceiro lugar permanecem em 10\%. Nesta situação, o índice $T$ se reduz de 0,7902 para 0,3366. Pode-se notar isso nas apresentações que quando o número de concorrentes aumenta em qualquer cidade, o valor obtido com o indicador tende a aumentar para uma mesma votação para o mais votado (Casos 1 e 2). Os Casos 3 e 4 indicam quão importante é a diferença entre os votos do candidato mais votado para o segundo lugar e deste para o terceiro. A observação apenas da votação do primeiro colocado em termos absolutos traz informações que não correspondem ao real grau de disputa eleitoral na cidade analisada. 
SILVA, G. P. Uma avaliação empírica da competição eleitoral para a Câmara Federal ...

Apêndice 2

Gráficos de Correlação entre o Índice T e o Número Efetivo de Partidos (NEP)
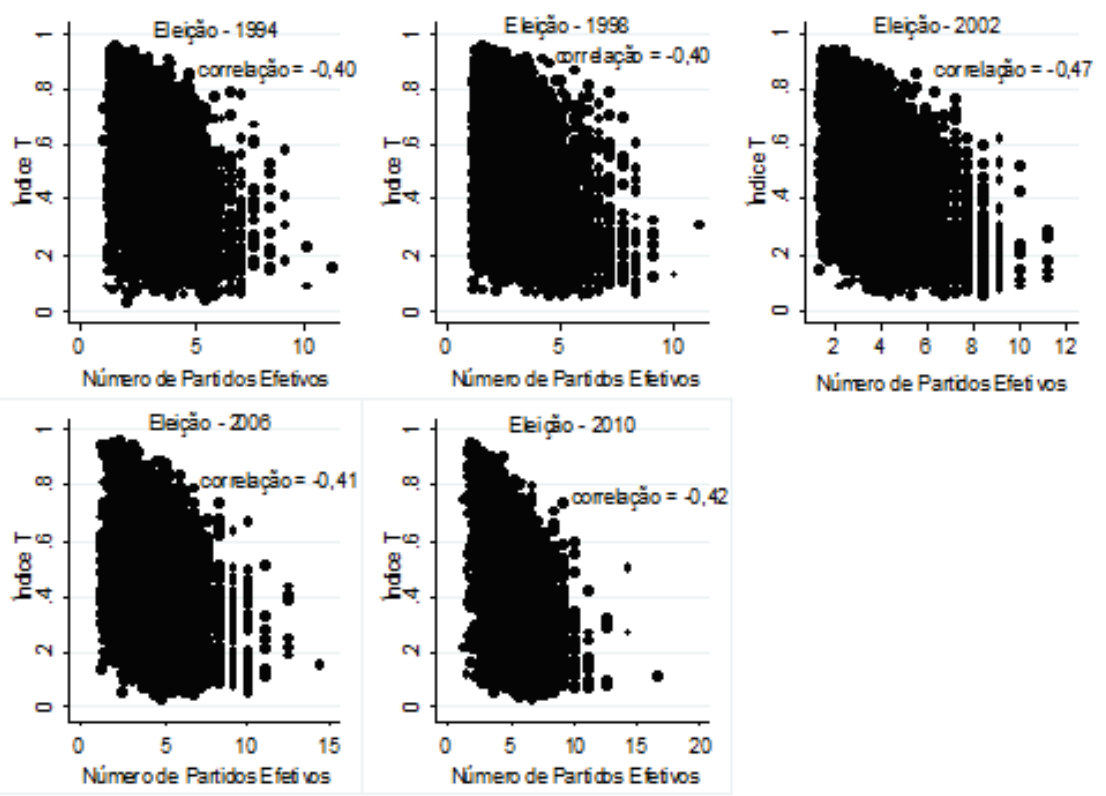

Glauco Peres da Silva - glauco.p.silva@gmail.com

Submetido à publicação em maio de 2012. Versão final aprovada em julho de 2013. 